\title{
Private and Public Sector Employer Actions for Home Office Workers During the COVID-19 Epidemic
}

doi:10.2478/mape-2021-0046

Date of submission to the Editor: 08/2021

Date of acceptance by the Editor: 09/2021

MAPE 2021, volume 4, issue 1, pp. 509-519

\section{Krzysztof Nowacki}

ORCID ID: 0000-0003-2925-084X

Silesian University of Technology, Poland

Sandra Grabowska

ORCID ID: 0000-0002-0478-3466

Silesian University of Technology, Poland

Teresa Lis

ORCID ID: 0000-0003-3664-5444

Silesian University of Technology, Poland

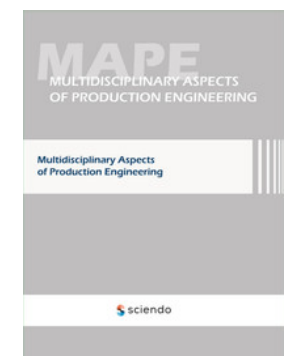

\section{INCRODUCTION}

The coronavirus (Covid-19) pandemic is one of the most impactful events of the $21^{\text {st }}$ century. The COVID-19 epidemic began on November 17, 2019 in Hubei Province, in the city of Wuhan in central China. It was declared a pandemic by the World Health Organization (WHO) on March 11, 2020. The World Health Organization initially did not recognize the epidemic as an international public health threat, although it warned that further spread of the disease was possible. In Poland, the first case of COVID-19 was diagnosed on 4 March 2020. The COVID-19 epidemic has changed the daily work organization of many companies. Whenever possible, the companies delegated their employees to work in the home office. Due to the growing number of COVID-19 cases in Poland and Europe, employers were forced to take quick steps to minimize the spread of the virus, ensure continuity of work and business operations (Cockburn, 2020).

The national legislator in Poland obliged employers to provide employees with disposable gloves or hand disinfectants. An obligation was introduced to maintain a distance between workstations of at least $1.5 \mathrm{~m}$, and in the absence of such a distance the use of personal protective equipment was ordered. Customer service stations should be regularly disinfected. Subsequent government guidelines have introduced an obligation to cover mouth and nose with disposable masks or visors. The Polish government has developed special procedures to ensure the greatest possible safety for employees in enterprises, recommending that:

- Avoiding the infection of employees with the COVID-19 virus by strangers,

- Limiting the number of physical contacts within the company,

- Creating small work teams,

- Use of non-contact temperature measurement 
- Employees and guests before entering the premises,

- Ensuring the protection of the faces and hands of all employees, limiting the use of common spaces (such as kitchens, corridors, etc.),

- Change in rest hours.

The COVID-19 epidemic has put the entrepreneurs in front of the necessity to deal with the hitherto unknown reality overnight. On the one hand, they have to ensure continuity of work/production on the other hand, they have to remember about the health and safety of employees, as well as customers and contractors. Managers were not prepared for management in such turbulent conditions. The developed procedures for dealing with unusual situations often contained guidelines - in the worst case, how to act during the war. But none of the companies were ready to operate during the epidemic. So far published research in the field of teleworking, crisis management, etc. are not helpful either, because they were not conducted in such an urgent and dangerous situation as the global epidemic (Robelski et al., 2019; Ruíz Castilla et al., 2019). Companies had to adapt to the new reality overnight, they could not afford to delay, such circumstances created a previously unknown background for research.

Many companies, however, have decided to send their employees to work in the home office, considering this solution to be the safest. Analyzing the literature contained in the Web of Science, Scopus or Google Scholar databases, a research gap was identified in the field of research related to crisis management during epidemics. The greatest attention of researchers is focused around Covid-19 from the health perspective. There is still a lack of research on management, ways of coping with this new, difficult, turbulent situation (Ali et al., 2020; Apergis and Apergis, 2020; Ding et al., 2020). The aim of the article is to assess the activities of employers from the private and state sectors in Poland, related to the delegation of employees to work in the home office, and to analyze the skills and possibilities of self-organization of work by employees. Hypothesis was adopted: There are differences in the possibilities of adapting to the crisis situation of public and private sector establishments. The differences become apparent in unprecedented situations for which scenarios are not normally developed. Then, employers who do not have crisis management scenarios developed rely on the involvement and creativity of employees, which depends on their age.

\section{MATERIAL AND METHODS}

The research material consisted of the results of a survey conducted among employees referred to work in the home office in connection with the announced state of the epidemic in Poland. The research was conducted in Poland in the period from July 31 to August 19, 2020. The respondents answered the questionnaire questions presented in Table 1. In addition to the questionnaire, data on the gender and age of the respondents, the sector of operation of the 
company (public, private) and the size of the company (small company with up to 49 employees, medium-sized company with up to 249 employees, large company with over 249 employees) were collected. The survey, due to the still existing restrictions on direct communication, was distributed on industry forums by means of social media. The results of the research are anonymous, no personal data was collected, the privacy of respondents or third parties was not violated.

Table 1 Research questionnaire

\begin{tabular}{|c|c|c|}
\hline $\begin{array}{l}\text { Question } \\
\text { No. }\end{array}$ & Question & Possible answers \\
\hline 1 & $\begin{array}{l}\text { Have you received guidelines from your employer } \\
\text { on how to organize remote working space at } \\
\text { home? }\end{array}$ & Yes; No \\
\hline 2 & $\begin{array}{l}\text { Has your employer equipped you with a computer } \\
\text { with remote working software? }\end{array}$ & $\begin{array}{l}\text { Yes; No; I do not use my } \\
\text { computer while working } \\
\text { in the home office }\end{array}$ \\
\hline 3 & $\begin{array}{l}\text { Has your employer equipped you with a telephone } \\
\text { for contacts during remote working? }\end{array}$ & $\begin{array}{l}\text { Yes; No; I do not use my } \\
\text { telephone while working } \\
\text { in the home office }\end{array}$ \\
\hline 4 & $\begin{array}{l}\text { Did the employer provide you with a Internet (or } \\
\text { does he refund the costs)? }\end{array}$ & $\begin{array}{l}\text { Yes; No; I do not use my } \\
\text { Internet while working } \\
\text { in the home office }\end{array}$ \\
\hline 5 & $\begin{array}{l}\text { If you take part in teleconferences, has the } \\
\text { employer trained you to use the software used } \\
\text { for teleconferences? }\end{array}$ & $\begin{array}{l}\text { Yes; No; I do not take part } \\
\text { in teleconferences }\end{array}$ \\
\hline 6 & $\begin{array}{l}\text { Do you work at home in one place adapted } \\
\text { for office work? }\end{array}$ & Yes; No \\
\hline 7 & $\begin{array}{l}\text { Do you always work from home on a computer } \\
\text { chair (5-arm base, armrests, adjustable seat } \\
\text { height, tilt angle, backrest etc.)? }\end{array}$ & Yes; No \\
\hline 8 & $\begin{array}{l}\text { Do you work remotely only during working hours } \\
\text { (e.g. 9-17)? }\end{array}$ & Yes; No \\
\hline 9 & $\begin{array}{l}\text { Do you need to be available by phone during } \\
\text { remote working hours? }\end{array}$ & Yes; No \\
\hline 10 & $\begin{array}{l}\text { Do you experience health problems in connection } \\
\text { with remote working, e.g. pain in your back, neck, } \\
\text { etc.? }\end{array}$ & Yes; No \\
\hline
\end{tabular}

Source: Own study

The results were analyzed statistically by means of a chi-quadrant $(\mathrm{RxC})$ test (Plackett 1983). For each of the conducted tests the confidence level $\alpha<0.05$ was assumed. The results were coded depending on the requirements of the method. The method of coding was presented each time the test results were presented.

\section{RESULTS}

In total, 199 questionnaires were collected, which allowed to reduce the estimation error $E$ to 0.07 . The age of the respondents ranged from 22 to 71 years (arithmetic mean 38.2, coefficient of variation 0.24 , median 38 , trend 38 ). The obtained results were collated and subjected to comparative statistical analysis by means of tests adequate to the scale. The total results are 
summarized in Table 2. The results of comparative analyses for particular criteria together with information about the applied test and the value of the parameter $p$ are summarized in Tables 3-6. The tables present the results which, in the opinion of the authors, have logical justification, while random dependencies, such as the influence of gender on the equipment of employees with a telephone, computer or the Internet, have been omitted. The $p<\alpha$ value justified the rejection of the zero hypothesis, assuming no statistically significant difference between the obtained results.

Table 2 Total results of the research

\begin{tabular}{|c|c|c|c|}
\hline Question No. & Answer & Population & Part (\%) \\
\hline \multirow{2}{*}{1} & Yes & 56 & 28.1 \\
\hline & No & 143 & 71.9 \\
\hline \multirow{3}{*}{2} & Yes & 130 & 65.3 \\
\hline & No & 66 & 33.2 \\
\hline & I do not use & 3 & 1.5 \\
\hline \multirow{3}{*}{3} & Yes & 94 & 47.2 \\
\hline & No & 95 & 47.7 \\
\hline & I do not use & 10 & 5.0 \\
\hline \multirow{3}{*}{4} & Yes & 34 & 17.1 \\
\hline & No & 164 & 82.4 \\
\hline & I do not use & 1 & 0.5 \\
\hline \multirow{3}{*}{5} & Yes & 87 & 43.7 \\
\hline & No & 87 & 12.6 \\
\hline & I do not take part in teleconferences & 21 & 67.4 \\
\hline \multirow{2}{*}{6} & Yes & 134 & 67.4 \\
\hline & No & 65 & 32.6 \\
\hline \multirow{2}{*}{7} & Yes & 67 & 33.7 \\
\hline & No & 132 & 66.3 \\
\hline \multirow{2}{*}{8} & Yes & 81 & 41.7 \\
\hline & No & 112 & 58.3 \\
\hline \multirow{2}{*}{9} & Yes & 170 & 85.4 \\
\hline & No & 29 & 14.6 \\
\hline \multirow{2}{*}{10} & Yes & 74 & 37.2 \\
\hline & No & 125 & 62.8 \\
\hline
\end{tabular}

Source: Own study

Table 3 Research results for the criterion of gender of respondents

\begin{tabular}{|c|c|c|c|c|c|c|}
\hline $\begin{array}{c}\text { Question } \\
\text { No. }\end{array}$ & Answer & \multicolumn{2}{|c|}{ Woman } & \multicolumn{2}{|c|}{ Man } & p (RxC \\
chi- \\
copulation & Part (\%) & Population & Part (\%) & $\begin{array}{c}\text { quadra } \\
\text { nt test) }\end{array}$ \\
\hline \multirow{2}{*}{6} & Yes & 87 & 67.2 & 47 & 67.7 & 0.864 \\
& No & 43 & 32.8 & 22 & 32.3 & \\
\hline \multirow{2}{*}{7} & Yes & 35 & 26.8 & 32 & 46.9 & \multirow{2}{*}{0.006} \\
\cline { 2 - 6 } & No & 95 & 73.2 & 37 & 53.1 & \\
\hline \multirow{2}{*}{8} & Yes & 55 & 42.1 & 25 & 36.7 & \multirow{2}{*}{0.405} \\
\cline { 2 - 6 } & No & 75 & 57.9 & 44 & 63.3 & \\
\hline \multirow{2}{*}{10} & Yes & 54 & 41.5 & 20 & 29.0 & \multirow{2}{*}{0.081} \\
\cline { 2 - 6 } & No & 76 & 59.6 & 49 & 71.0 & \\
\hline
\end{tabular}

Source: Own study 
Table 4 Research results for the criterion sector

\begin{tabular}{|c|c|c|c|c|c|c|}
\hline \multirow{2}{*}{$\begin{array}{c}\text { Question } \\
\text { No. }\end{array}$} & \multirow[t]{2}{*}{ Answer } & \multicolumn{2}{|c|}{ Public sector } & \multicolumn{2}{|c|}{ Private sector } & \multirow{2}{*}{$\begin{array}{l}\text { p (RxC } \\
\text { chi- } \\
\text { quadra } \\
\text { nt test) }\end{array}$} \\
\hline & & Population & Part (\%) & Population & Part (\%) & \\
\hline \multirow{2}{*}{1} & Yes & 12 & 18.2 & 44 & 33.1 & \multirow[t]{2}{*}{0.028} \\
\hline & No & 54 & 81.8 & 89 & 66.9 & \\
\hline \multirow{3}{*}{2} & Yes & 30 & 45.5 & 100 & 75.2 & \multirow[t]{3}{*}{$<0.001$} \\
\hline & No & 35 & 53.0 & 31 & 23.3 & \\
\hline & I do not use & 1 & 1.5 & 2 & 1.5 & \\
\hline \multirow{3}{*}{3} & Yes & 8 & 12.1 & 86 & 64.7 & \multirow[t]{3}{*}{$<0.001$} \\
\hline & No & 57 & 86.4 & 38 & 27.6 & \\
\hline & I do not use & 1 & 1.5 & 9 & 6.8 & \\
\hline \multirow{3}{*}{4} & Yes & 2 & 3.0 & 32 & 24.1 & \\
\hline & No & 64 & 97.0 & 100 & 75.2 & \\
\hline & I do not use & 0 & 00 & 1 & 0.7 & \\
\hline \multirow{3}{*}{5} & Yes & 19 & 28.8 & 68 & 51.1 & \multirow[t]{3}{*}{0.001} \\
\hline & No & 36 & 54.4 & 51 & 38.4 & \\
\hline & I do not & 11 & 16.7 & 14 & 10.5 & \\
\hline \multirow{2}{*}{8} & Yes & 20 & 29.7 & 61 & 46.2 & \multirow[t]{2}{*}{0.035} \\
\hline & No & 46 & 70.3 & 72 & 53.8 & \\
\hline \multirow{2}{*}{9} & Yes & 55 & 86.3 & 115 & 86.5 & \multirow[t]{2}{*}{0.555} \\
\hline & No & 11 & 16.7 & 18 & 13.5 & \\
\hline \multirow{2}{*}{10} & Yes & 33 & 50.0 & 41 & 30.8 & \multirow[t]{2}{*}{0.008} \\
\hline & No & 33 & 50.0 & 92 & 69.2 & \\
\hline
\end{tabular}

Source: Own study

Table 5 Research results for the criterion of company size

\begin{tabular}{|c|c|c|c|c|c|c|c|c|}
\hline \multirow{2}{*}{$\begin{array}{c}\text { Question } \\
\text { No. }\end{array}$} & \multirow[t]{2}{*}{ Answer } & \multicolumn{2}{|c|}{ Small } & \multicolumn{2}{|c|}{ Medium } & \multicolumn{2}{|c|}{ Big } & \multirow{2}{*}{$\begin{array}{c}\text { p (RxC } \\
\text { chi- } \\
\text { quadrant } \\
\text { test) }\end{array}$} \\
\hline & & Pop. & $\begin{array}{l}\text { Part } \\
\text { (\%) }\end{array}$ & Pop. & $\begin{array}{l}\text { Part } \\
\text { (\%) }\end{array}$ & Pop. & $\begin{array}{l}\text { Part } \\
\text { (\%) }\end{array}$ & \\
\hline \multirow{2}{*}{1} & Yes & 4 & 15.4 & 12 & 20.3 & 40 & 35.1 & \multirow{2}{*}{0.037} \\
\hline & No & 22 & 84.6 & 47 & 79.7 & 74 & & \\
\hline \multirow{3}{*}{2} & Yes & 11 & 50.0 & 45 & 76.3 & 72 & 63.1 & \multirow{3}{*}{0.015} \\
\hline & No & 13 & 42.3 & 14 & 23.7 & 41 & 36.0 & \\
\hline & I do not use & 2 & 7.7 & 0 & 0.0 & 1 & 0.9 & \\
\hline \multirow{3}{*}{3} & Yes & 11 & 42.3 & 32 & 54,2 & 51 & 44.7 & \multirow{3}{*}{0.471} \\
\hline & No & 14 & 53.7 & 26 & 40.1 & 55 & 48.3 & \\
\hline & I do not use & 1 & 3.8 & 1 & 1.7 & 8 & 7.0 & \\
\hline \multirow{3}{*}{4} & Yes & 1 & 3.9 & 12 & 20.3 & 21 & 18.4 & \multirow{3}{*}{0.038} \\
\hline & No & 24 & 92.3 & 47 & 79.7 & 93 & 81.6 & \\
\hline & I do not use & 1 & 3.8 & 0 & 0.0 & 0 & 0.0 & \\
\hline \multirow{3}{*}{5} & Yes & 11 & 39.3 & 19 & 32.2 & 59 & 51.8 & \multirow{3}{*}{0.004} \\
\hline & No & 9 & 32.1 & 30 & 50.9 & 4 & 42.1 & \\
\hline & I do not & 8 & 28.6 & 10 & 16.9 & 7 & 6.1 & \\
\hline \multirow[b]{2}{*}{8} & Yes & 2 & 9.1 & 22 & 36.8 & 56 & 49.0 & \multirow[b]{2}{*}{0.001} \\
\hline & No & 24 & 90.9 & 37 & 63.2 & 58 & 51.0 & \\
\hline \multirow{2}{*}{9} & Yes & 23 & 88.5 & 54 & 91.5 & 93 & 81.6 & \multirow{2}{*}{0.191} \\
\hline & No & 3 & 11.5 & 5 & 8.5 & 21 & 18.4 & \\
\hline \multirow[b]{2}{*}{10} & Yes & 10 & 38.5 & 22 & 37.3 & 42 & 36.8 & \multirow{2}{*}{0.988} \\
\hline & No & 16 & 61.5 & 37 & 62.7 & 72 & 63.2 & \\
\hline
\end{tabular}

Source: Own study 
Table 6 Research results for the criterion of age of respondents

\begin{tabular}{|c|c|c|c|c|c|c|c|c|}
\hline \multirow{2}{*}{$\begin{array}{c}\text { Question } \\
\text { No. }\end{array}$} & \multirow[t]{2}{*}{ Answer } & \multicolumn{2}{|c|}{ up to 30 years } & \multicolumn{2}{|c|}{$31-50$ years } & \multicolumn{2}{|c|}{ over 50 years } & \multirow{2}{*}{$\begin{array}{c}\text { p (RxC } \\
\text { chi- } \\
\text { quadrant } \\
\text { test) }\end{array}$} \\
\hline & & Pop. & Part (\%) & Pop. & Part (\%) & Pop. & Part (\%) & \\
\hline \multirow{2}{*}{1} & Yes & 23 & 48.9 & 31 & 23.3 & 2 & 10.5 & \multirow{2}{*}{0.001} \\
\hline & No & 24 & 51.1 & 102 & 76.7 & 17 & 89.5 & \\
\hline \multirow{2}{*}{6} & Yes & 27 & 58.1 & 91 & 68.3 & 16 & 83.3 & \multirow{2}{*}{0.099} \\
\hline & No & 20 & 41.9 & 42 & 31.7 & 3 & 16.7 & \\
\hline \multirow{2}{*}{7} & Yes & 15 & 31.8 & 44 & 33.1 & 8 & 42.1 & \multirow{2}{*}{0.708} \\
\hline & No & 32 & 68.2 & 89 & 66.9 & 11 & 57.9 & \\
\hline \multirow{2}{*}{8} & Yes & 27 & 56.8 & 46 & 34.5 & 7 & 38.9 & \multirow{2}{*}{0.022} \\
\hline & No & 20 & 43.2 & 87 & 65.5 & 12 & 61.1 & \\
\hline \multirow{2}{*}{10} & Yes & 18 & 38.3 & 47 & 35.3 & 9 & 47.4 & \multirow{2}{*}{0.588} \\
\hline & No & 29 & 61.7 & 86 & 64.7 & 10 & 52.6 & \\
\hline
\end{tabular}

Source: Own study

\section{DISCUSSION}

Office work done in the home office, apparently does not require much in terms of its organization. In the XXI century it can be assumed that the organization of this type of work does not depend on the industry, size of the company or age of the employee. This is usually a typical office work. However, like any work, to be safe and above all comfortable and effective it requires proper organization of the place to work. Although in many cases the employer has no influence on the final conditions of the employee's home office, the quality of these conditions may depend on the employer's guidelines for organizing the remote workplace. The results of the research indicate that in total, about $28 \%$ of employees have received guidelines from employers on how to organize remote working space at home. Twice as many times as $33.1 \%$ and $18.2 \%$ of the employees were given such recommendations by private rather than public sector employers. In addition, a statistically significant correlation was found between the size of the company and the development of such guidelines. The research showed that employees of small enterprises employing up to 49 people equipped with such guidelines only $15.4 \%$ of people referred to work in the home office, while in medium-sized enterprises this percentage was $20.3 \%$ and in large ones $35.1 \%$. The results obtained allow us to conclude that during a crisis situation, when in practice from one day to the next employees were sent to work in the home office, large companies (especially those from the private sector) managed to cope with this situation much better organizationally.

In addition to the guidelines, employers should equip employees with the necessary means of work. Employees in $98.5 \%$ of cases stated that they used a computer and thus the Internet (99.5\%) while working in the home office, and $87.6 \%$ of respondents took part in teleconferences. Moreover, employers in more than $85 \%$ of cases expected employees to be available on the phone while working in the home office, which resulted in $95 \%$ of cases where employees used the phone while working remotely. On this basis it can be concluded that employers, when directing employees to remote work, should provide them with at least a computer with the required software and access to the Internet and a 
telephone, and possibly reimburse the costs related to the employee's use of the Internet and telephone connection. The results of the research indicate that more than $65 \%$ of employees were equipped by employers with computer equipment, with the private sector equipping $75 \%$ of employees and the state sector only $45 \%$. Analyzing the above issue taking into account the size of the enterprise, it was found that medium enterprises (76.3\%) and large enterprises $(63.1 \%)$ equipped a higher percentage of employees than small enterprises (50\%) with computer equipment.

Working in the home office in the XXI century requires access to the Internet. This is due to the necessity to access both external and internal information located e.g. in the cloud. Research has shown that only in $17.1 \%$ of cases employers have provided or reimbursed employees for the costs of Internet access. It is noteworthy that in the budgetary sphere, the Internet signal was provided by employers to only $3 \%$ of employees, while in the private sector it was over $24 \%$. Similar differences were observed in the case of enterprise size, where in small enterprises only $3.9 \%$ of employees were provided with Internet access by the employer, while in medium and large enterprises it was $18-20 \%$. It is also important to note that in the case of medium and large companies, all employees sent to work in the home office used the Internet. The need to maintain communication between employer and employee or between employees also required access to a telephone. Employers in almost half of the cases (47.7\%), during the epidemic, supported communication within the company with private phones of employees. In the case of the state sector, only $12.1 \%$ of the employees assigned to work in the home office were equipped with a telephone, while in the private sector this percentage was $64.7 \%$ of the employees.

Another type of internal and external communication in companies were teleconferences. The employer, expecting such a form of work from the employee, should provide him/her with training in their use. The research showed that half of the employees taking part in teleconferences were trained by the employers in this area, and as in previous cases it was much more often in the private sector $(51.1 \%)$ than in the state sector $(28.8 \%)$. It was found that large companies trained $51.8 \%$ of employees in this area, while the percentage in small and medium-sized enterprises was $39.3 \%$ and $32.2 \%$ respectively.

Employers' guidelines are the basis for organizing work in the home office. However, the final form and space of work depends on the employee himself, his housing situation, family, age and even gender. About $67 \%$ of people perform their work in one subsidized place. However, differences in the equipment of the workplace between men and women were observed. $26.8 \%$ of women indicated that their workplace is equipped with a chair adapted to work with a computer, while $46.9 \%$ of men's workplaces are equipped with such equipment. The overall result of $33.7 \%$ in this respect indicates large deficiencies in equipping workplaces with home office. These observations can be confirmed by the percentage of people indicating health problems related to 
work in the home office, among women it was $41.5 \%$ and among men $29.0 \%$ of respondents. Among the most common health effects were spinal pains, dizziness, numbness in arms and legs.

The organization of the workplace depends on behavioural factors, which depend on the age of the employees. It was found that employees experienced over 50 years of age in $83.3 \%$ of cases perform work in a home office in one place adapted for office work, while among young workers under 30 years of age this percentage was only $58.1 \%$. A similar correlation was obtained in the case of adapting the workplace to work with a computer, where with the age of the respondents an increase in the proportion of people using this type of equipment was found, but in this case the observations were not confirmed by statistical significance $(p=0.708)$.

The age of employees is related to their experience and, consequently, often their professional position (Chung et al., 2014; Maqsoom et al., 2018). Senior employees usually perform work with greater responsibility, managing specific projects and human teams. The youngest employees often perform task-based work, limited in time and scope. This type of division of tasks is connected with time expenditure on their performance, also during work in the home office. It was found that more than half $(58.8 \%)$ of people up to 30 years old work remotely only during working hours agreed with the employer, while in the group of employees over 50 years old, this percentage was only $38.9 \%$. These differences may also result from generational differences, in the approach to their work duties and the so-called work ethos. The generation of the so-called Millenniums differently, generation $Y$ (born in 1984-1994) constitute an important part of the labour market, but it is estimated that they will play a dominant role on it only around 2025. Currently, the most important are still those representing the Baby Boomers generation (born 1946-1964) and the $X$ generation (born 1965-1979). They are most often the owners of large companies and the bosses and superiors of generation $Y$ and $Z$ (born after 1994). In a sense, this is confirmed by the percentage of people under 30 years of age to whom employers provided guidelines on how to organize work in the home office $(18.9 \%)$, while from people over 50 years of age, treated as leaders, employers expected their own initiative by providing guidelines on how to organize remote workspace only $10.5 \%$ of people. The representatives of the Baby Boomers generation identify themselves with the work ethos - the most important thing for them is commitment to their duties, their values and loyalty to their employer or to their company. They are said to be people who live to work. The Baby Boomers generation often dedicates itself to work without regard for its negative aspects. Generation $\mathrm{X}$ is more concerned with balancing private and professional life, finding the golden mean, but in reality it is often the job that dominates their lives. Unlike previous generations, it is said that generation $\mathrm{Y}$ is working to live, it is important for them to maintain a work-lifebalance. They are ready to devote about 8 hours a day to their work, but they 
value their free time and guard it (Anderson et al., 2017; Campbell et al., 2020; Davis et al., 2020).

Studies presented in recent years related to remote working indicate that people prefer to work from home rather than in an office located in the company's headquarters, that the home office has a positive impact on personal work experience (Beno, 2018). This is particularly desirable among e.g. programmers (Ruzi Castilla, 2019). This form of work causes less stress and generates time savings associated with commuting to work in densely populated areas. An alternative to working in the homme office can be coworking spaces (Robelski et al., 2019), which, in comparison to the home office, are also a space acceptable to employees to work. Unfortunately, in a pandemic situation, the use of this type of space is excluded, so employees must do their work at home. The results of published studies confirm that many people have received only a laptop and little education, if any, on e.g. the ergonomic configuration of the workplace. As a result, many workers working from home may not have optimal working conditions. The chances of accessing a properly organized home office depend on the size of the company (Davis et al., 2020).

To sum up, the results of the research indicate that the private sector has prepared its employees much better for the work in the home office to which they were referred in connection with the COVID-19 outbreak. Such a situation may be related to the better financial condition of the private sector, its greater mobility and the ability to adapt to the changing situation on the market, related, for example, to the legally unlimited possibility of purchasing equipment. The state sector, with public funds at its disposal, has no legal possibility to suddenly purchase additional equipment or services, which in many cases require a tender procedure under the Public Procurement Act. Another reason for the differences may be the dependence of the private sector on the market situation. Regardless of whether employees work or not, the private sector must generate a profit that covers the company's current liabilities. The state sector, which is education, public offices and their subordinate companies, is financed from the state budget, is not so strongly dependent on the market situation, and this results in greater time inertia in decision-making, also in terms of home office efficiency.

\section{CONCLUSION}

The outbreak of the COVID-19 epidemic forced rapid changes in the daily work of many companies. These changes were to ensure continuity of work on the one hand, and on the other hand to ensure the safety of employees. The way out of this difficult situation was to send employees to work in the home office. The results of the research indicate that in a crisis situation, the private sector has adapted much better to changes in work organization. The private sector employees were better equipped and more were trained in teleworking than those employed in the public sector. 
State authorities should better prepare the budget sector for crisis situations forcing changes in work organization, including teleworking. These changes should allow for greater decision-making and flexibility for those who make decisions related to public money management, within the existing law. Such actions will improve the functioning of the public sector, mainly in the administrative and educational sphere.

The presented results are one of the first empirical studies conducted in a crisis situation forced by a pandemic, requiring sudden changes in the organization of work by enterprises. Subsequent research should be aimed at finding correlations between the level of organization, industrial sector, cultural and behavioral factors and home office work organization and the social and health effects of home office work.

\section{ACKNOWLEDGEMENTS}

Silesian University of Technology (Faculty of Materials Engineering, Department of Production Engineering) supported this work as a part of Statutory Research BK-229/RM1/2021 (11/010/BK_21/0032).

\section{REFERENCES}

Cockburn, W. (2020). Poradnik UE, COVID-19: Return to employment, Adapting the workplace and protecting workers, European Agency for Safety and Health at Work (EU-OSHA).

WHO's guide Getting your workplace ready for COVID-19. Availabel at: https://www.who.int/docs/default-source/coronaviruse/getting-workplace-readyfor-covid-19.pdf - WHO's guide Getting your workplace ready for COVID-19 [Accessed 23 Jun. 2020].

Robelski, S.; Keller, H.; Harth, V.; Mache, S. (2019). Coworking Spaces: The Better Home Office? A Psychosocial and Health-Related Perspective on an Emerging Work Environment. Int. J. Environ. Res. Public Health, 16, 2379.

Ruíz Castilla J.S., Cervantes Canales J., Arévalo Zenteno D., Hernández Santiago J. (2019). HOMSI, a Home-Office Model for the Software Industry in the Big Cities of Mexico. In: Botto-Tobar M., Barzola-Monteses J., Santos-Baquerizo E., Espinoza-Andaluz M., Yánez-Pazmiño W. (eds) Computer and Communication Engineering. ICCCE 2018. Communications in Computer and Information Science, 959. Springer, Cham. https://doi.org/10.1007/978-3-030-12018-4_7.

Beno, M. (2018). Working in the virtual world - an approach to the "home office" business model analysis. Ad alta-journal of interdisciplinary research, Volume: 8 Issue: 1 pp. 25-36.

Ali, M., N. Alam, and S. A. R. Rivzi. (2020). Coronavirus (COVID-19) - An epidemic or pandemic for financial markets. Journal of Behavioral and Experimental Finance, 27, doi:10.1016/j.jbef.2020.100341.

Apergis, E., and N. Apergis. (2020). Can the COVID-19 pandemic and oil prices drive the US Partisan conflict index? Energy Research Letters, 1(1):13144. doi:10.46557/001c.13144

Ding, W., R. Levine, C. Lin, and W. Xie. Corporate immunity to the COVID-19 pandemic. NBER Working Paper 2020 No. 27055. National Bureau of Economic Research, Cambridge, MA. Availabel at: https://www.nber.org/papers/w27055.pdf [Accessed 08 Sep. 2020].

Chung, J., Park, J., Cho, M., Park, Y., Kim, D., Yang, D., Yang, Y. (2014). A study on the relationships between age, work experience, cognition, and work ability in 
older employees working in heavy industry. J. Phys. Ther. Sci, 27, p. 155-157 doi: 10.1589/jpts.27.155

Maqsoom,A., Mughees, A., Safdar,U., Afsar, B., ul AliZeeshan, B. (2108). Intrinsic psychosocial stressors and construction worker productivity: impact of employee age and industry experience. Economic Research-Ekonomska Istraživanja, 31(1), pp. 1880-1902, doi: 10.1080/1331677X.2018.1495571

Anderson, H., Baur, J., Griffith, J. (2017). What works for you may not work for (Gen) Me: Limitations of present leadership theories for the new generation. Leadership Quarterly, 28( 1), pp. 245-260.

Campbell, W., Campbell, S., Siedor, L. (2020). Generational Differences Are Real and Useful. Industrial and Organizational Psychology-Perspectives on Science and Practice, 8(3) pp. 324-331

Davis, K.G., Kotowski, S.E., Daniel, D., Gerding, T., Naylor, J., Syck, M. (2020) The Home Office: Ergonomic Lessons From the "New Normal". Ergonomics in Design: The Quarterly of Human Factors Applications, doi:10.1177/1064804620937907

\begin{abstract}
A research was conducted among the employees referred to work in the home office in connection with the announced state of the epidemic in Poland. The research was conducted using a questionnaire method, the study was attended by 199 respondents. The research is burdened with an error in the selection of statistical sample units, which resulted from the respondents' involvement and their truthfulness. The aim of the article is to assess the activities of employers from the private and state sectors in Poland, related to the delegation of employees to work in the home office, and to analyze the skills and possibilities of self-organization of work by employees. An important result of the survey was to demonstrate the differences in the behavior of public and private sector employers. The study shows that the private sector has adapted better to sudden changes than the state sector.
\end{abstract}

Keywords: home office, epidemic, COVID-19, activities of employers, work flexibility, job satisfaction, work efficiency 